\title{
Selective Separation and Analysis of Catecholamines in Urine Based on Magnetic Solid Phase Extraction by Mercaptophenylboronic Acid Functionalized $\mathrm{Fe}_{3} \mathrm{O}_{4}-\mathrm{NH}_{2} @ \mathrm{Au}$ Magnetic Nanoparticles Coupled with HPLC
}

\author{
Qing Han ${ }^{1}$, Xiaoxiao $\mathrm{Wu}^{1}{ }^{1}$, Yi Cao ${ }^{2}$, Hua Zhang ${ }^{2}$, Yuqin Zhao ${ }^{3}$, Xuejun Kang ${ }^{1, *}$ and Huaiyuan Zhu ${ }^{2, *}$ \\ 1 Key Laboratory of Child Development and Learning Science, Ministry of Education, \\ Research Center for Learning Science, School of Biological Sciences \& Medical Engineering, \\ Southeast University, Nanjing 210096, China; hanqing_exploring@163.com (Q.H.); \\ 15952085778@163.com (X.W.) \\ 2 China Tobacco Jiangsu Industrial Co., Ltd., Nanjing 210019, China; caoyi@jszygs.com (Y.C.); \\ zhanghua@jszygs.com (H.Z.) \\ 3 Jiangsu Provincial Hospital of Traditional Chinese Medicine, Nanjing 210001, China; quinty0718@126.com \\ * Correspondence: 101006214@seu.edu.cn (X.K.); zhuhy@jszygs.com (H.Z.); \\ Tel.: +86-025-83795664-1011 (X.K.); +86-025-69896736 (H.Z.)
}

Citation: Han, Q.; Wu, X.; Cao, Y.; Zhang, H.; Zhao, Y.; Kang, X.; Zhu, H. Selective Separation and Analysis of Catecholamines in Urine Based on Magnetic Solid Phase Extraction by Mercaptophenylboronic Acid Functionalized $\mathrm{Fe}_{3} \mathrm{O}_{4}-\mathrm{NH}_{2} @ \mathrm{Au}$ Magnetic Nanoparticles Coupled with HPLC. Separations 2021, 8, 196 https://doi.org/10.3390/

separations 8110196

Academic Editor: Solmaz Hajizadeh

Received: 13 September 2021

Accepted: 12 October 2021

Published: 20 October 2021

Publisher's Note: MDPI stays neutral with regard to jurisdictional claims in published maps and institutional affiliations.

Copyright: (c) 2021 by the authors. Licensee MDPI, Basel, Switzerland. This article is an open access article distributed under the terms and conditions of the Creative Commons Attribution (CC BY) license (https:// creativecommons.org/licenses/by/ $4.0 /)$.

\begin{abstract}
A novel magnetic solid phase extraction based on mercaptophenylboronic acid (MPBA)functionalized $\mathrm{Fe}_{3} \mathrm{O}_{4}-\mathrm{NH}_{2} @ \mathrm{Au}$ nanomaterial $\left(\mathrm{Fe}_{3} \mathrm{O}_{4}-\mathrm{NH}_{2} @ \mathrm{Au}-\mathrm{MPBA}\right.$ ) was developed for selective separation and enrichment of catecholamines (including dopamine, norepinephrine and adrenaline). $\mathrm{Fe}_{3} \mathrm{O}_{4}-\mathrm{NH}_{2} @ \mathrm{Au}-\mathrm{MPBA}$ nanoparticles were achieved by self-assembly-anchoring MPBA molecules on the surface of $\mathrm{Fe}_{3} \mathrm{O}_{4}-\mathrm{NH}_{2} @$ Au nanocomposites, which were synthesized via a facial ultrasonic auxiliary in situ reduction process. The interaction between cis-diol from catecholamines and boronic acid was reversible and could be flexibly controlled by adjusting $\mathrm{pH}$ value. The catecholamines could be quickly adsorbed by $\mathrm{Fe}_{3} \mathrm{O}_{4}-\mathrm{NH}_{2} @ \mathrm{Au}-\mathrm{MPBA}$ in weak alkaline solution ( $\mathrm{pH}$ 8.0-9.0) and subsequently released in acid solution $(\mathrm{pH}$ 1.0-2.0). The process of adsorption and dissociation was very fast. Furthermore, the three catecholamines could be detected in urine from children by high performance liquid chromatography (HPLC) with electrochemical detector. Under optimal conditions, norepinephrine (NE), epinephrine (EP) and dopamine (DA) were separated very well from internal standard and exhibited a good linearity in the range of $2.5-500.0 \mathrm{ng} \mathrm{mL} \mathrm{m}^{-1}$, with correlation coefficients of $r^{2}>0.9907$. Limits of detection (LOD) (signal to noise $=3$ ) were $0.39,0.27$ and $0.60 \mathrm{ng} \mathrm{mL}^{-1}$ for NE, EP and DA, respectively. Recoveries for the spiked catecholamines were in the range of $85.4-105.2 \%$ with the relative standard deviation (RSD) $<11.5 \%$.
\end{abstract}

Keywords: $\mathrm{Fe}_{3} \mathrm{O}_{4}-\mathrm{NH}_{2} @ \mathrm{Au}$; magnetic solid phase extraction; catecholamines; HPLC; electrochemical detection; urine

\section{Introduction}

Catecholamines (CAs), which include norepinephrine (NE), epinephrine (EP) and dopamine (DA), are important neurotransmitters and hormones released by the adrenal glands and sympathetic nervous system [1]. Currently, it is known that catecholamines are involved in some of the most prevalent human pathologies, such as neurological disorders such as Parkinson's [2], pheochromocytoma [3] and schizophrenia [4]. Hence, monitoring the concentration of catecholamines in biological fluids including blood, urine and specific tissue has attracted considerable interest in diagnostic analysis and biological systems [5,6].

In spite of the great diversity of analytical approaches that have been developed in recent years, the detection of catecholamines in biological samples remains a hot spot in analytical fields [7,8]. High-performance liquid chromatography (HPLC) is an analytical 
method routinely used for the separation and quantification of catecholamines in clinical laboratories [9,10], usually coupled with electrochemical [11], fluorescence [12] or mass spectrometry detection [13]. Among the detectors, electrochemical detectors [14,15] attract more preference due to good selectivity, highly sensitive characteristics, a lack of need for derivatization and low detection cost. However, matrix effects, extremely low concentrations and chemical instability of catecholamines in biological samples are major difficulties encountered in their analysis.

To solve these problems, optimization of the sample pretreatment process plays an important role in the enrichment and separation of targets. The common sample preparation methods for extracting catecholamines in chromatographic analysis involves liquidliquid extraction (LLE) [16] and solid phase extraction (SPE) [17,18]. Nevertheless, LLE is labor-intensive and time-consuming [19] and encounters low selectivity and extraction yields. SPE is widely adopted for the extraction and concentration of catecholamines, possibly due to the high extraction recoveries and selectivity [20].

Magnetic solid phase extraction (MSPE) is a flexible solid phase extraction technology. The magnetic adsorbents can be recycled and reused easily, which is cost-effective and environmentally friendly. $\mathrm{Fe}_{3} \mathrm{O}_{4}$ magnetic nanoparticles (NPs), commonly used magnetic cores, are easily oxidized in air and have a tendency to aggregate [21,22]. To overcome these problems, different materials such as metals [23], metal oxides [24], mesoporous [25], polymers [26], graphene [27] and dendrimers [28] have been developed to hybridize with $\mathrm{Fe}_{3} \mathrm{O}_{4}$ NPs. In recent years, gold-coated $\mathrm{Fe}_{3} \mathrm{O}_{4}\left(\mathrm{Fe}_{3} \mathrm{O}_{4} @ \mathrm{Au}\right)$ magnetic NPs have drawn intense scientific and technological interest for potential applications in disease diagnosis and therapy [29], biological detection [30], catalytic application and separation science [31].

In recent years, phenylboronic acid (PBA) and its derivatives containing boronic acid functional groups have been employed for selective capture and enrichment of cisdiol molecules (carbohydrates [32], mucin [33], nucleosides and glycoconjugates) from biological samples. Owing to the ability to form a five- or six-membered boronate ester [34] via reversible covalent interactions with the position at cis-1, 2- or 1,3-diol, they exhibit a high selectivity for targets. The formation and dissociation of boronic esters are controlled by appropriately adjusting the $\mathrm{pH}$ value. 4-mercaptophenylboronic acid (4-MPBA) is a thiol-containing boronic acid compound which has been used to modify gold NPs for the selective interactions with cis-diol structure on sugars [35], sialic acid, protein kinase and alpha-fetoprotein [36-39]. However, to the best of our knowledge, we have not seen this idea used for the selective separation of catecholamines.

In this report, a novel magnetic nanocomposite, 4-MPBA-functionalized $\mathrm{Fe}_{3} \mathrm{O}_{4}-\mathrm{NH}_{2} @ \mathrm{Au}$ $\left(\mathrm{Fe}_{3} \mathrm{O}_{4}-\mathrm{NH}_{2} @ \mathrm{Au}-\mathrm{MPBA}\right)$, was prepared and used for the pretreatment of catecholamines in urine and followed by HPLC-electrochemical detection. The cis-diol structures of catecholamines were able to form ring boronate ester structures with boronic acid groups of $\mathrm{Fe}_{3} \mathrm{O}_{4}-\mathrm{NH}_{2} @ \mathrm{Au}-\mathrm{MPBA}$ nanocomposite by covalent bond interaction. The morphologies and magnetization saturation values of the prepared magnetic material were explored by scanning electron microscope (SEM) and vibrating sample magnetometer (VSM). The analytical performances of the method were evaluated before determining catecholamines in urine samples.

\section{Materials and Methods}

\subsection{Reagents and Chemicals}

Dopamine (DA) and norepinephrine (NE) were purchased from Yuanye biotechnology Co., Ltd. (Shanghai, China). Epinephrine (EP) was bought from Chromadex (Irvine, CA, USA). 3,4-dihydroxybenzylamine hydrobromide (DHBA) acting as internal standard (IS) was purchased from Aladdin Reagent (Shanghai, China). 4-mercaptophenylboronic acid (MPBA) was bought from Sinopharm Chemical Reagent Co., Ltd. (Shanghai, China). Molecular structures of these compounds are shown in Figure 1. 
<smiles>NCC(O)c1ccc(O)c(O)c1</smiles>

NE<smiles>NCCc1ccc(O)c(O)c1</smiles>

DA

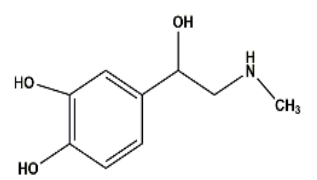

EP

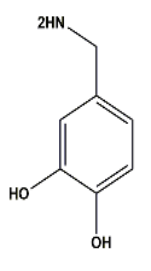

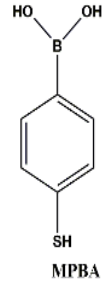

Figure 1. Molecular structures of these compounds.

Stock solutions $\left(1 \mathrm{mg} \mathrm{mL}^{-1}\right)$ of NE, DA and IS were prepared by dissolving $5 \mathrm{mg}$ of standard substance in $5 \mathrm{~mL}$ of deionized water. Stock solution $\left(1 \mathrm{mg} \mathrm{mL}{ }^{-1}\right)$ of EP was prepared by dissolving $5 \mathrm{mg}$ of standard substance in $100 \mu \mathrm{L} 0.01 \mathrm{~mol} \mathrm{~L}^{-1} \mathrm{HCl}$ solution before diluting to $5 \mathrm{~mL}$ by deionized water. All solutions were stored at $-20{ }^{\circ} \mathrm{C}$ until use.

The artificial urine reported in the reference [40] was used in recovery tests. The artificial urine consisted of $19.4 \mathrm{mg} \mathrm{mL}^{-1}$ of urea, $8.0 \mathrm{mg} \mathrm{mL}^{-1}$ of NaCl, $1.1 \mathrm{mg} \mathrm{mL}^{-1}$ of magnesium sulfate and $0.6 \mathrm{mg} \mathrm{mL}^{-1}$ of $\mathrm{CaCl}_{2}$, and the solution was adjusted to $\mathrm{pH} 8.0$ with $1 \mathrm{~mol} \mathrm{~L}^{-1} \mathrm{NaOH}$. Spiked artificial urine solution was prepared containing CAs (NE, $\mathrm{EP}$ and DA) in the concentrations of 10,50 and $200 \mathrm{ng} \mathrm{mL} \mathrm{m}^{-1}$, and then $2 \mathrm{~mL}$ of the spiked solution was mixed with $100 \mu \mathrm{L}$ of IS $\left(1000 \mathrm{ng} \mathrm{mL}^{-1}\right)$.

\subsection{Instruments}

A pH meter (Shanghai, China) with a composite electrode was used for the $\mathrm{pH}$ values. Special indicator papers indicating $\mathrm{pH}$ 6.9-8.4 were bought from SSS Reagent Company (Shanghai, China). An analytical balance (Shanghai, China) was used for weight measurement. A Hitachi S-3400N scanning electron microscope (SEM, Hitachi, Tokyo, Japan) was used at an acceleration voltage of $20.0 \mathrm{kV}$. Magnetic measurement was carried out using a 7407 vibrating sample magnetometer (Lakeshore, Columbus, OH, USA) at room temperature.

\subsection{Chromatography Conditions}

A Thermo Scientific UltiMate 3000 ECD UHPLC system based on a glass carbon electrode detector (Thermo Fisher Scientific, Waltham, MA, USA) equipped with a Kromasil $\mathrm{C}_{18}$ column $(5 \mu \mathrm{m}, 250 \mathrm{~mm} \times 4.6 \mathrm{~mm})$ was used. The mobile phase was isocratic elution and consisted of acetonitrile and $0.7 \% \mathrm{NaH}_{2} \mathrm{PO}_{4}$ in water $(5.5: 94.5, v / v)$ with addition of citric acid ( $\left.35 \mathrm{mmol} \mathrm{L}^{-1}\right)$, EDTA $\left(0.25 \mathrm{mmol} \mathrm{L}^{-1}\right)$ and 1-heptane sulfonic acid sodium salt $\left(2 \mathrm{mmol} \mathrm{L}{ }^{-1}\right)$. The $\mathrm{pH}$ of the mobile phase was adjusted to $\mathrm{pH} 4.0$ by adding saturated $\mathrm{NaOH}$ solution. The run was performed at $1.0 \mathrm{~mL} \mathrm{~min}^{-1}$ with the column oven temperature at $30{ }^{\circ} \mathrm{C}$. The injection volume was $20 \mu \mathrm{L}$ and the working potential was $700 \mathrm{mV}$.

\subsection{Preparation of Phenylboronic Acid-Functionalized $\mathrm{Fe}_{3} \mathrm{O}_{4}-\mathrm{NH}_{2} @ A u\left(\mathrm{Fe}_{3} \mathrm{O}_{4}-\mathrm{NH}_{2} @ A u-M P B A\right)$}

The $\mathrm{Fe}_{3} \mathrm{O}_{4}$ NPs were prepared through reducing the solution of Fe (II) and Fe (III) chlorides of the molar ratio 1:2 with 30\% ammonia solution. Appropriate $\mathrm{Fe}_{3} \mathrm{O}_{4} \mathrm{NPs}$ were modified by APTES through stirring in 10\% $(v / v)$ APTES solution in absolute ethyl alcohol for $12 \mathrm{~h}$. The obtained $\mathrm{Fe}_{3} \mathrm{O}_{4}$ NPs modified by $-\mathrm{NH}_{2}$ groups $\left(\mathrm{Fe}_{3} \mathrm{O}_{4}-\mathrm{NH}_{2}\right)$ were magnetically separated, washed with ethanol and dispersed in ethanol.

Next, $500 \mathrm{mg} \mathrm{Fe} \mathrm{O}_{4}-\mathrm{NH}_{2}$ NPs, $50 \mathrm{~mL}$ of $2 \% \mathrm{HAuCl}_{4}$ and $300 \mathrm{~mL}$ distilled water were mixed for over $10 \mathrm{~min}$ by sonication, and then $50 \mathrm{mmol} \mathrm{L}{ }^{-1} \mathrm{KBH}_{4}$ solution was dropped into the above mixture under ultrasound until the color changed to purple. Another 5 min of sonication was performed. The $\mathrm{Fe}_{3} \mathrm{O}_{4}-\mathrm{NH}_{2} @ \mathrm{Au} \mathrm{NPs}$ were obtained by magnetic separation.

An amount of $500 \mathrm{mg} \mathrm{Fe} \mathrm{O}_{4}-\mathrm{NH}_{2} @ \mathrm{Au}$ NPs was added to $100 \mathrm{~mL} 1 \mathrm{mg} \mathrm{mL}^{-1}$ of MPBA solution under stirring to complete the covalent binding between the Au shell and sulfydryl (-SH). $\mathrm{Fe}_{3} \mathrm{O}_{4}-\mathrm{NH}_{2} @ \mathrm{Au}-\mathrm{MPBA}$ composites were obtained, then separated and washed with distilled water based on external magnetic field. After that, the magnetic nanocomposites were dried in a vacuum oven at $40{ }^{\circ} \mathrm{C}$ for $24 \mathrm{~h}$. 


\subsection{Sample Collection}

To investigate the suitability of the proposed method, a pilot study was conducted by analyzing urinary samples from healthy volunteers. The urine samples from 6 healthy children aged 4-6 years ( 3 boys and 3 girls). Their morning urine samples were collected into sterile urine cups. They were then immediately transferred to polypropylene tubes and stored in a $-20^{\circ} \mathrm{C}$ refrigerator.

The study was carried out according to the principles of the Declaration of Helsinki (World Medical Association 2008). Written informed consent was obtained from the legal guardians of the volunteers. This study was approved by the Ethics Committee of Zhongda Hospital Affiliated to Southeast University.

\subsection{Sample Pretreatment}

When analyzing samples, the stored $2.5 \mathrm{~mL}$ urine samples were thawed by incubation at $37^{\circ} \mathrm{C}$ for $5 \mathrm{~min}$ and centrifuged for $5 \mathrm{~min}$ at 10,000 rpm. Then, $2 \mathrm{~mL}$ of supernatant, $100 \mu \mathrm{L}$ of $1 \mu \mathrm{g} \mathrm{mL}{ }^{-1}$ DHBA and $5 \mathrm{mg} \mathrm{Fe}_{3} \mathrm{O}_{4}-\mathrm{NH}_{2} @ \mathrm{Au}-\mathrm{MPBA}$ NPs were added into a glass spawn bottle, and the $\mathrm{pH}$ was adjusted to 8.0 by adding moderate amounts of $0.01 \mathrm{~mol} \mathrm{~L}^{-1}$ $\mathrm{NaOH}$. After that, the mixture was stirred for about $10 \mathrm{~min}$ at room temperature, and the supernatant was removed by external magnetic field. An amount of $200 \mu \mathrm{L}$ of $0.5 \%$ $\mathrm{H}_{3} \mathrm{PO}_{4}$ solution $(\mathrm{pH}=2.0$ ) was added for desorbing the analytes. $20 \mu \mathrm{L}$ of eluent was injected into HPLC for analysis. The process schematic for the preparation of the magnetic $\mathrm{Fe}_{3} \mathrm{O}_{4}-\mathrm{NH}_{2} @ \mathrm{Au}-\mathrm{MPBA}$ NPs and the pretreatment of samples are shown in Figure 2.
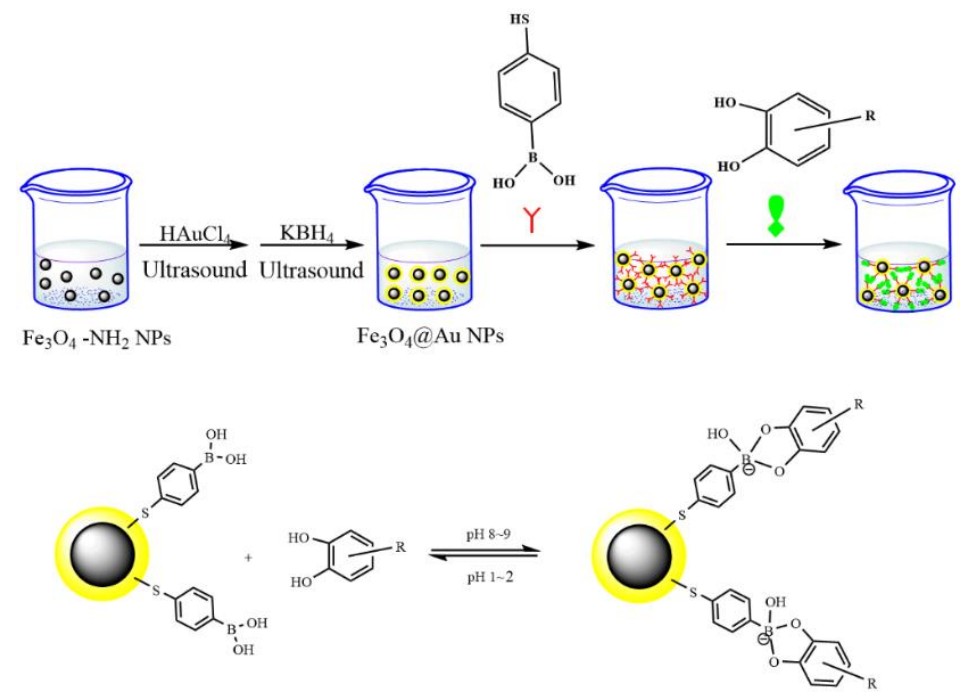

Figure 2. Schematic representation for the preparation of $\mathrm{Fe}_{3} \mathrm{O}_{4}-\mathrm{NH}_{2} @ A u-M P B A$ NPs and the extraction of CAs.

\section{Results and Discussion}

\subsection{Characterization}

The morphologies of $\mathrm{Fe}_{3} \mathrm{O}_{4}-\mathrm{NH}_{2} @ \mathrm{Au}$ NPs were examined by SEM at $20.0 \mathrm{kV}(8.2 \mathrm{~mm}$, 40.0k SE) (Figure 3A). The size distribution of $\mathrm{Fe}_{3} \mathrm{O}_{4}-\mathrm{NH}_{2} @ \mathrm{Au}$ NPs is shown in Figure 3B, where we can see that the size of $\mathrm{Fe}_{3} \mathrm{O}_{4}-\mathrm{NH}_{2} @ \mathrm{Au}$ NPs was uniform, and the average particle size was about $150 \mathrm{~nm}$. The energy-dispersive spectroscopy (EDS) results showed the existence of $\mathrm{Fe}, \mathrm{C}, \mathrm{Si}$ and $\mathrm{O}$ elements in $\mathrm{Fe}_{3} \mathrm{O}_{4}-\mathrm{NH}_{2}$ samples (Figure 3C). Moreover, the $\mathrm{Au}$ elements could be found in $\mathrm{Fe}_{3} \mathrm{O}_{4}-\mathrm{NH}_{2} @ \mathrm{Au}$ material (Figure 3D), which indicated that $\mathrm{Fe}_{3} \mathrm{O}_{4}-\mathrm{NH}_{2} @ \mathrm{Au}$ NPs were successfully prepared. 

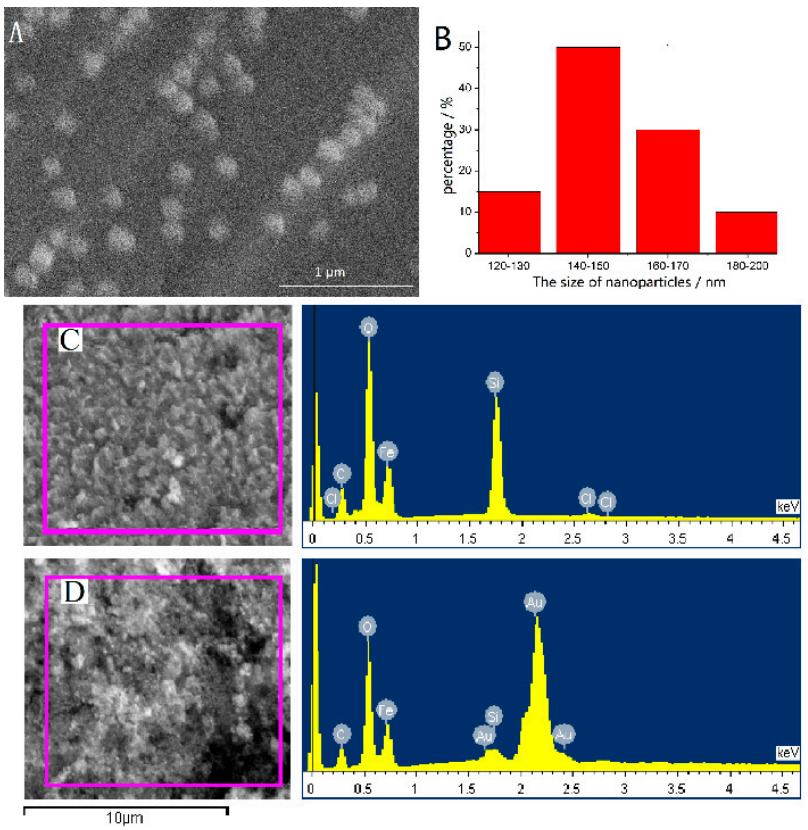

Figure 3. SEM (A) and the size distribution (B) of $\mathrm{Fe}_{3} \mathrm{O}_{4}-\mathrm{NH}_{2} @ \mathrm{Au}$ NPs. The EDSs of $\mathrm{Fe}_{3} \mathrm{O}_{4}-\mathrm{NH}_{2}$ (C) and $\mathrm{Fe}_{3} \mathrm{O}_{4}-\mathrm{NH}_{2} @ \mathrm{Au}$ NPs powder (D).

The profile of magnetization loops in Figure 4 revealed that the $\mathrm{Fe}_{3} \mathrm{O}_{4}-\mathrm{NH}_{2}$ and $\mathrm{Fe}_{3} \mathrm{O}_{4}-\mathrm{NH}_{2} @ \mathrm{Au} \mathrm{NPs}$ are superparamagnetic [29]. The magnetization saturation (Ms) values of $\mathrm{Fe}_{3} \mathrm{O}_{4}-\mathrm{NH}_{2}$ and $\mathrm{Fe}_{3} \mathrm{O}_{4}-\mathrm{NH}_{2} @ \mathrm{Au}$ NPs were determined as 32.1 and $22.0 \mathrm{emu} / \mathrm{g}$, respectively. The $\mathrm{Fe}_{3} \mathrm{O}_{4}-\mathrm{NH}_{2} @ \mathrm{Au} \mathrm{NPs}$ showed slightly lower Ms values than that of $\mathrm{Fe}_{3} \mathrm{O}_{4}-\mathrm{NH}_{2}$ due to the surface conjugation of Au NPs on $\mathrm{Fe}_{3} \mathrm{O}_{4}-\mathrm{NH}_{2}$.

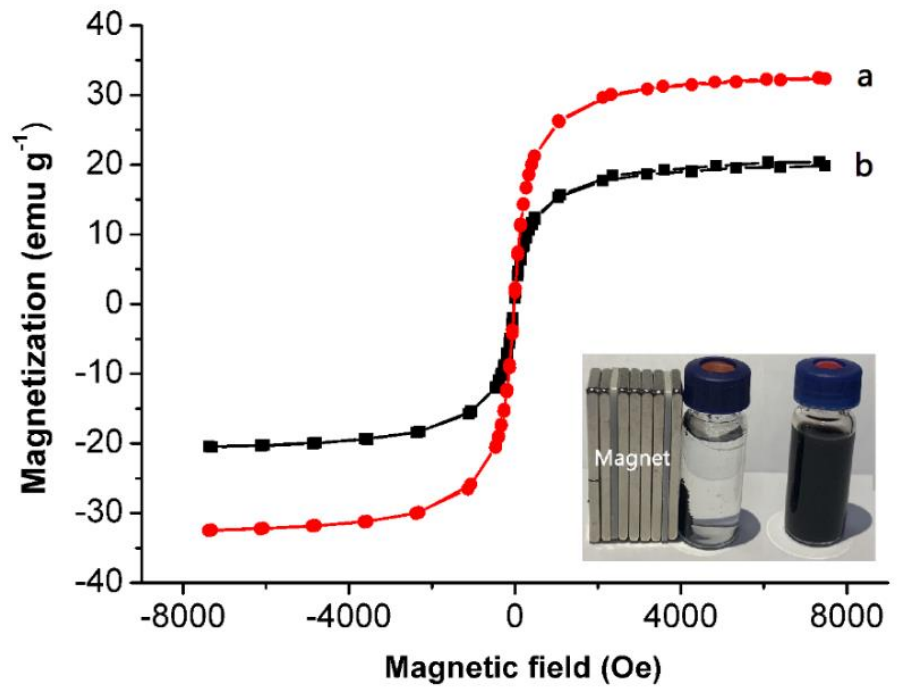

Figure 4. VSMs of $\mathrm{Fe}_{3} \mathrm{O}_{4}-\mathrm{NH}_{2}(\mathbf{a})$ and $\mathrm{Fe}_{3} \mathrm{O}_{4}-\mathrm{NH}_{2} @ \mathrm{Au} \mathrm{NPs}(\mathbf{b})$. The two bottles in the inset are both $\mathrm{Fe}_{3} \mathrm{O}_{4}-\mathrm{NH}_{2} @ \mathrm{Au}$ NPs samples.

In the inset, the two bottles are both $\mathrm{Fe}_{3} \mathrm{O}_{4}-\mathrm{NH}_{2} @ \mathrm{Au}$ NPs suspension solution. The composite NPs were able to be magnetically separated by an external magnetic field, which indicated that the enrichment and separation of $\mathrm{Fe}_{3} \mathrm{O}_{4}-\mathrm{NH}_{2} @ \mathrm{Au} \mathrm{NPs}$ during the extraction process can be regulated by an external magnetic field. 


\subsection{Optimization of the Extraction Condition}

\subsubsection{Optimizing the Mass Ratio of $\mathrm{Au}^{3+}$ and $\mathrm{Fe}_{3} \mathrm{O}_{4}-\mathrm{NH}_{2}$}

The effect of the mass ratios of $\mathrm{Fe}_{3} \mathrm{O}_{4}-\mathrm{NH}_{2}$ and $\mathrm{Au}^{3+}$ on magnetic separation time was studied. As shown in Figure $5 \mathrm{~A}$, when the mass ratio of $\mathrm{Fe}_{3} \mathrm{O}_{4}-\mathrm{NH}_{2}$ and $\mathrm{Au}^{3+}$ was 3:1, the magnetic separation time was less than 2 minutes; however, too little $\mathrm{Au}^{3+}$ may reduce the functionalized molecule numbers of MPBA, which would reduce the sites of interaction for targets. With the increase in $\mathrm{Au}^{3+}$, the magnetic separation time was gradually prolonged. However, when the mass ratio was 1:2, the gold nanoparticles were not completely wrapped on the surface of $\mathrm{Fe}_{3} \mathrm{O}_{4}-\mathrm{NH}_{2} \mathrm{NPs}$, which was very wasteful for $\mathrm{Au}^{3+}$. When the mass ratio was 1:1.5, the magnetic separation time was 15 minutes, which was too long for rapid pretreatment for samples. Therefore, the mass ratio of 1:1 between $\mathrm{Fe}_{3} \mathrm{O}_{4}-\mathrm{NH}_{2} \mathrm{NPs}$ and $\mathrm{Au}^{3+}$ was chosen.
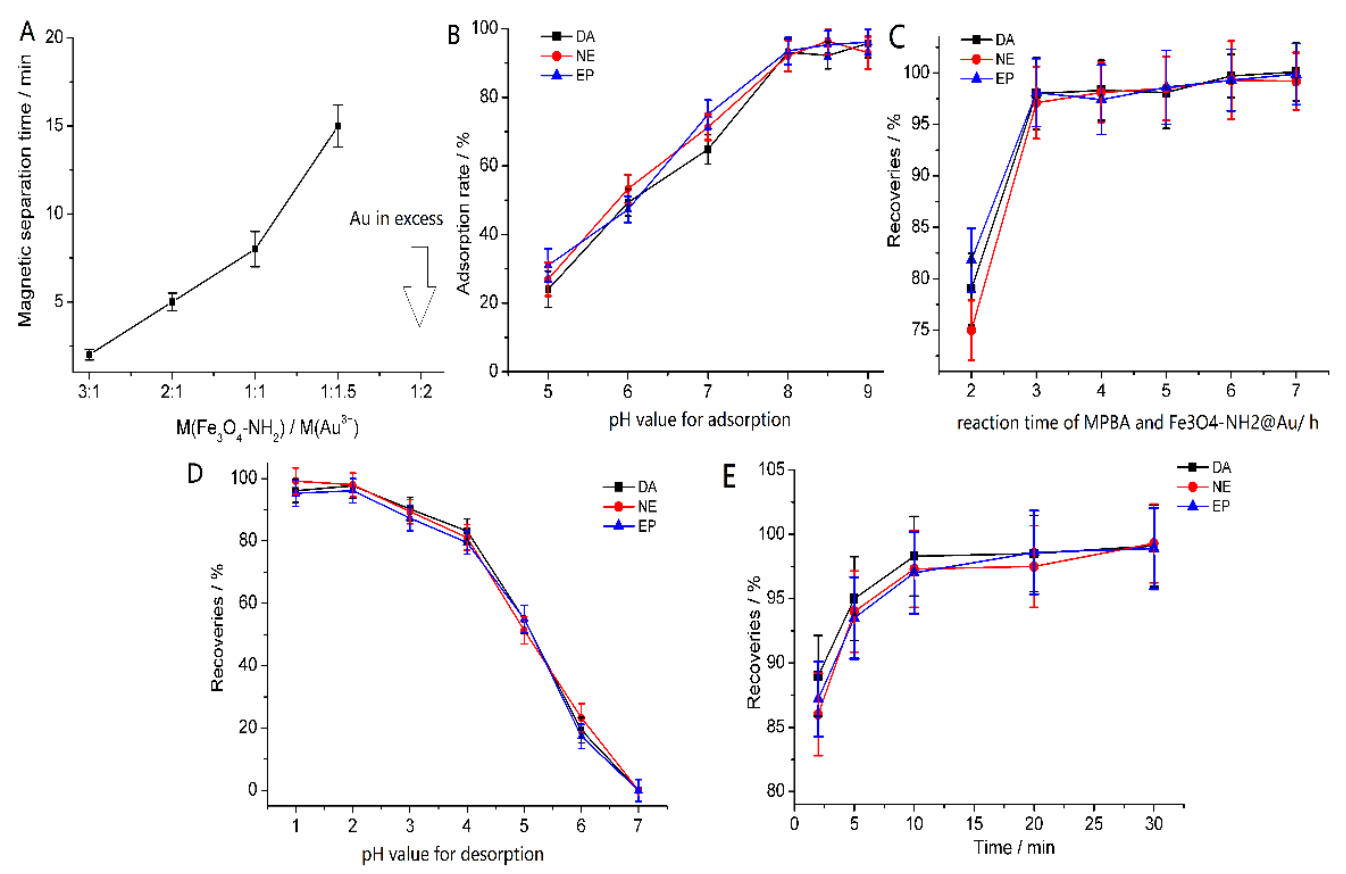

Figure 5. Optimizing the mass ratio of $\mathrm{Fe}_{3} \mathrm{O}_{4}-\mathrm{NH}_{2}$ and $\mathrm{Au}^{3+}(\mathrm{A})$, the $\mathrm{pH}$ value of adsorption solution (B), the reaction time of MPBA and $\mathrm{Fe}_{3} \mathrm{O}_{4}-\mathrm{NH}_{2} @ \mathrm{Au} \mathrm{NPs}(\mathbf{C})$, the $\mathrm{pH}$ value of desorption solvent (D) and elution time (E).

\subsubsection{Optimizing the $\mathrm{pH}$ Value of the Adsorption Solution}

The $\mathrm{pH}$ value of adsorption solution was a critical factor for boronate affinity. Most boronic acids are generally weak acids, having a $\mathrm{pKa}$ values of 8.0-9.0. With $\mathrm{pH}$ less than the $\mathrm{pKa}$ value, most of them still exist in trigonal form $\left[-\mathrm{B}(\mathrm{OH})_{2}\right]$, which cannot react with cis-diol groups [41]. For phenylboronic acids, when the $\mathrm{pH}$ is greater than the $\mathrm{pKa}$ value of the phenylboronic acid ligand, the phenylboronic acid group is transformed to tetrahedral anionic form $\left[-\mathrm{B}(\mathrm{OH})_{4}{ }^{-}\right]$under alkaline conditions [35]. Subsequently, $\left[-\mathrm{B}(\mathrm{OH})_{4}{ }^{-}\right]$bonds with cis-1,2-diol units to form a stable 5-membered cyclic ester. This is in good agreement with the results obtained from MPBA functionalized $\mathrm{Fe}_{3} \mathrm{O}_{4}-\mathrm{NH}_{2} @ \mathrm{Au}$. In this work, we studied the effect of adsorption $\mathrm{pH}$ value (5.0-9.0) on adsorption performance, and the results are shown in Figure 5B. As described above, the phenylboronic acids were the sole functional group on $\mathrm{Fe}_{3} \mathrm{O}_{4}-\mathrm{NH}_{2} @ \mathrm{Au}$ nanoparticles, and thus the adsorption rates of adsorbents for the three catecholamines were $\mathrm{pH}$-dependent. The adsorption rates improved when the $\mathrm{pH}$ value increased from 5.0 to 8.0 and then remained almost unchanged. Thus, $\mathrm{pH} 8.0$ was selected for adsorption. 


\subsubsection{Optimizing Reaction Time of MPBA and $\mathrm{Fe}_{3} \mathrm{O}_{4}-\mathrm{NH}_{2} @ \mathrm{Au}$}

The interaction time between MPBA and $\mathrm{Fe}_{3} \mathrm{O}_{4}-\mathrm{NH}_{2} @ \mathrm{Au}$ NPs is very important, as it could impact the adsorption performance of the magnetic NPs for catecholamines. The relationships between reaction time (2-7 h) and extraction efficiency were explored. As shown in Figure 5C, when reaction time was more than $3 \mathrm{~h}$, the extraction efficiency remained nearly unchanged. Thus, $3 \mathrm{~h}$ was chosen as the reaction time of MPBA and $\mathrm{Fe}_{3} \mathrm{O}_{4}-\mathrm{NH}_{2} @ \mathrm{Au} \mathrm{NPs}$.

\subsubsection{The $\mathrm{pH}$ Value of Desorption Solvent}

The $\mathrm{pH}$ value of the eluent has an important effect on the formation of boronate ester, because the reversible covalent interactions could be adjusted by $\mathrm{pH}$ between the positions of the cis-diol moieties of the targets and the hydroxyl groups of the boronic acid ligand. Acidic environments can break the ester bond and make the target dissociate from $\mathrm{Fe}_{3} \mathrm{O}_{4}$ $\mathrm{NH}_{2} @ \mathrm{Au}-\mathrm{MPBA}$ NPs. The $\mathrm{pH}$ value (1.0-7.0) was investigated for the eluent. With the decrease in $\mathrm{pH}$ value of the eluent, the extraction recovery of the targets increased gradually. When the $\mathrm{pH}$ value was 2.0, the extraction recovery of the CAs reached the maximum. As the $\mathrm{pH}$ value continued to decrease, the recoveries almost remained unchanged. Therefore, $\mathrm{pH} 2.0$ was chosen as the acidity value for the eluent (Figure 5D).

\subsubsection{Exploring the Elution Time}

In order to obtain the best extraction performance, different elution time from 2 to 30 min was optimized. Figure 5E demonstrated the relationship between the elution time and the recoveries. When elution time was shorter than $10 \mathrm{~min}$, the extraction recovery increased with the extraction time increasing. When elution time was longer than $10 \mathrm{~min}$, the recovery of CAs was almost no longer changed. Therefore, $10 \mathrm{~min}$ was chosen as the final elution time.

\subsection{Method Evaluation}

To test the linearity, we analyzed the mixed solutions of NE, EP and DA at the concentrations of 2.5, 5.0,10.0, 20.0, 100.0 and $500.0 \mathrm{ng} / \mathrm{mL}$ for each target, which were prepared using artificial urine. Quantification was worked out using internal standard (IS) method. The calibration equation was calculated by the HPLC-ECD peak areas ratio and the concentration ratios of analytes and IS. The analysis performances of the established method for the detection of catecholamines are summarized in Table 1.

Table 1. Parameters for methodological validation for catecholamines in artificial urine.

\begin{tabular}{|c|c|c|c|c|c|c|c|c|}
\hline Catecholamines & $\begin{array}{l}\text { Linear Range } \\
\left(\text { (ng } \mathrm{mL}^{-1}\right)\end{array}$ & $\mathbf{r}^{2}$ & $\begin{array}{l}\text { Spiked Concentration } \\
\left(\mathrm{ng} \mathrm{mL}^{-1}\right)\end{array}$ & $\begin{array}{l}\text { Recovery } \\
(\%)\end{array}$ & $\begin{array}{c}\text { LOD } \\
\left.\text { (ng mL } \mathrm{mL}^{-1}\right)\end{array}$ & $\begin{array}{c}\text { LOQ } \\
\left(\mathrm{ng} \mathrm{mL}^{-1}\right)\end{array}$ & $\begin{array}{l}\text { Intraday } \\
\text { (RSD, \%) }\end{array}$ & $\begin{array}{l}\text { Interday } \\
\text { (RSD, \%) }\end{array}$ \\
\hline \multirow{4}{*}{ DA } & \multirow{4}{*}{$2.5-500.0$} & \multirow{4}{*}{0.9907} & 10.0 & 85.4 & \multirow{4}{*}{0.60} & \multirow{4}{*}{2.0} & 8.2 & 9.3 \\
\hline & & & 50.0 & 93.2 & & & 7.7 & 8.8 \\
\hline & & & 200.0 & 95.7 & & & 6.1 & 7.4 \\
\hline & & & 10.0 & 88.1 & & & 7.9 & 11.5 \\
\hline \multirow[t]{3}{*}{$\mathrm{NE}$} & \multirow{3}{*}{$2.5-500.0$} & \multirow[t]{3}{*}{0.9911} & 50.0 & 96.3 & \multirow[t]{3}{*}{0.39} & \multirow[t]{2}{*}{1.3} & 8.4 & 8.1 \\
\hline & & & 200.0 & 97.1 & & & 6.6 & 9.0 \\
\hline & & & 10.0 & 89.6 & & & 10.7 & 8.6 \\
\hline \multirow[t]{2}{*}{$\mathrm{EP}$} & \multirow[t]{2}{*}{$2.5-500.0$} & \multirow[t]{2}{*}{0.9935} & 50.0 & 98.3 & \multirow[t]{2}{*}{0.27} & \multirow[t]{2}{*}{0.9} & 8.3 & 7.9 \\
\hline & & & 200.0 & 105.2 & & & 8.9 & 8.1 \\
\hline
\end{tabular}

The intra-day and inter-day precision and accuracy were evaluated for artificial urine samples spiked with catecholamines at the concentrations of 10,50 and $200 \mathrm{ng} \mathrm{mL}^{-1}$ based on the above pretreatment method. The limits of detection (LOD), defined as the signal-tonoise ratio of 3:1, and limits of quantification (LOQ), defined as a signal-to-noise ratio of 10:1, were calculated; the results are listed in Table 1. Results showed that good linearity of the targets was achieved in the range of 2.5-500.0 ng mL ${ }^{-1}$ with the correlation coefficients $\left(\mathrm{r}^{2}\right)$ of $0.9911,0.9935$ and 0.9907 for NE, EP and DA, respectively. The LOQ were 1.3, 0.9 and $2.0 \mathrm{ng} \mathrm{mL}^{-1}(\mathrm{~S} / \mathrm{N}=10)$, and $\mathrm{LOD}(\mathrm{S} / \mathrm{N}=3)$ were $0.39,0.27$ and $0.60 \mathrm{ng} \mathrm{mL}^{-1}$ for $\mathrm{NE}$, 
EP and DA, respectively. The RSDs (relative standard deviations) for the catecholamines were from $6.1 \%$ to $10.7 \%$ for intra-day determination $(n=5)$ and from $7.4 \%$ to $11.5 \%$ for inter-day determination $(n=5)$.

The comparison of recoveries obtained by the present method and a reference method [42] has been added in Table S1 in the Supplementary. The results showed that the prepared method has good extraction recoveries for catecholamines.

\subsection{Reproducibility and Stability}

The relative standard deviation (RSD, \%) of adsorption quantities was $8.1 \%$ for six batches of $\mathrm{Fe}_{3} \mathrm{O}_{4}-\mathrm{NH}_{2} @ \mathrm{Au}-\mathrm{MPBA}$ NPs, and 7.3\% for one batch used 10 times. The adsorption capacities of $\mathrm{Fe}_{3} \mathrm{O}_{4}-\mathrm{NH}_{2} @ \mathrm{Au}-\mathrm{MPBA}$ NPs for catecholamines decreased by approximately $7.5 \%$ after one month. The data above showed that the prepared magnetic composite nanoparticles were a reliable and stable adsorbent for catecholamines.

\subsection{Application of the Method to Real Samples}

To evaluate the application of the prepared magnetic $\mathrm{Fe}_{3} \mathrm{O}_{4}-\mathrm{NH}_{2} @ \mathrm{Au}-\mathrm{MPBA} \mathrm{NPs}$, urine samples were analyzed using internal standard method. As shown in Figure 6, A was the liquid chromatogram of CAs at $20 \mathrm{ng} \mathrm{mL}^{-1}$ in artificial urine with the extraction by magnetic NPs. The liquid chromatogram of a real urine sample (Figure 6B) without the pretreatment by $\mathrm{Fe}_{3} \mathrm{O}_{4}-\mathrm{NH}_{2} @ \mathrm{Au}-\mathrm{MPBA}$ NPs exhibited many impurity peaks. Figure $6 \mathrm{C}$ was the liquid chromatogram of a real urine sample with the pretreatment by $\mathrm{Fe}_{3} \mathrm{O}_{4}{ }^{-}$ $\mathrm{NH}_{2} @ \mathrm{Au}-\mathrm{MPBA}$ NPs, where we can find fewer impurity peaks compared with Figure 6B. The results showed that $\mathrm{Fe}_{3} \mathrm{O}_{4}-\mathrm{NH}_{2} @ \mathrm{Au}-\mathrm{MPBA}$ NPs have a highly selective adsorption for catecholamines.

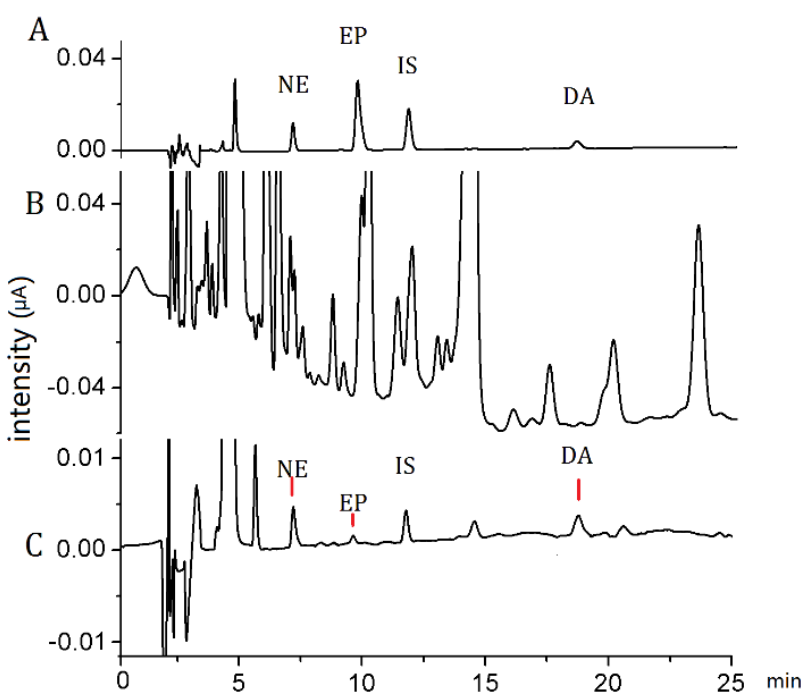

Figure 6. Liquid chromatograms of the mixed standard solution of CAs in artificial urine at $20 \mathrm{ng} \mathrm{mL}^{-1}$ with the extraction by magnetic NPs (A), (B) urine sample without extraction by magnetic NPs, (C) real urine sample with extraction by magnetic NPs.

First morning urinations, free of interference of medications and foods, were collected. Free catecholamines were measured in the morning urine samples from six healthy children using our developed method. The concentrations of CAs (NE, EP and DA) of the samples detected by the prepared method are shown in Table 2. The results showed that $\mathrm{Fe}_{3} \mathrm{O}_{4}{ }^{-}$ $\mathrm{NH}_{2} @$ Au-MPBA NPs coupled with HPLC-ECD could be successfully used for the detection of CAs. 
Table 2. The concentration of CAs (NE, EP, DA) in real urine samples ( $\pm \mathrm{SD}, n=3)$.

\begin{tabular}{cccc}
\hline \multirow{2}{*}{ Samples } & \multicolumn{3}{c}{ Level of Catecholamines $(\mathbf{M}+\mathbf{S D}, \mathbf{n g} / \mathbf{m L})(\boldsymbol{n}=\mathbf{3})$} \\
\cline { 2 - 4 } & $\mathbf{N E}$ & $\mathbf{E P}$ & $\mathbf{D A}$ \\
\hline 1 & $13.2 \pm 0.7$ & $10.8 \pm 0.3$ & $81.1 \pm 9.9$ \\
2 & $26.3 \pm 1.1$ & $25.3 \pm 1.5$ & $99.1 \pm 10.1$ \\
3 & $65.8 \pm 5.4$ & $21.1 \pm 1.7$ & $279.3 \pm 21.6$ \\
4 & $52.6 \pm 4.1$ & $43.2 \pm 3.5$ & $135.1 \pm 14.7$ \\
5 & $65.8 \pm 6.7$ & $22.6 \pm 1.9$ & $9.0 \pm 0.8$ \\
6 & $11.2 \pm 0.8$ & $2.7 \pm 0.1$ & $15.1 \pm 1.3$ \\
\hline
\end{tabular}

\section{Conclusions}

$\mathrm{Fe}_{3} \mathrm{O}_{4}-\mathrm{NH}_{2} @ \mathrm{Au}-\mathrm{MPBA}$ magnetic nanocomposites were synthesized in a simple method first and employed as adsorbents for the selective extraction of NE, EP and DA based on external magnetic field. 4-MPBA was modified on the surface of $\mathrm{Fe}_{3} \mathrm{O}_{4}-\mathrm{NH}_{2} @ \mathrm{Au}$ $\mathrm{NPs}$ through Au-S bond. The interaction between catecholamines and $\mathrm{Fe}_{3} \mathrm{O}_{4}-\mathrm{NH}_{2} @ \mathrm{Au}-$ MPBA magnetic NPs is based on the covalent bond of borate ester. The adsorption and desorption of catecholamines could be easily achieved through flexibly adjusting the $\mathrm{pH}$ value of solution. The SPE based on magnetic nanocomposite coupled with HPLCelectrochemical detection for the separation and analysis of catecholamines in human urine exhibited good sensitivity and selectivity.

Supplementary Materials: The following are available online at https: / www.mdpi.com/article/10 .3390 / separations8110196/s1, Figure S1: The SEM graph of PS-PCE, Table S1: The comparison of the extraction recoveries for the mixed catecholamines standard in artificial urine at the concentration of $100 \mathrm{ng} / \mathrm{mL}$ extracted by the present method and a reference method.

Author Contributions: Methodology, Q.H., Y.C., Y.Z. and H.Z. (Hua Zhang); formal analysis, Q.H.; resources, Y.Z., H.Z. (Huaiyuan Zhu). and X.K.; data curation, Q.H. and X.W.; writing-original draft preparation, Q.H.; writing-review and editing, X.K. funding acquisition, X.K. All authors have read and agreed to the published version of the manuscript.

Funding: We thank the National Key Research and Development Plan of China (No. 2018YFF0215204), the National Science Foundation of China (No. 81673230) and the Social Development Research Program of Jiangsu Province Science and Technology department (Project No. BE2020627) for their financial support.

Institutional Review Board Statement: The study was conducted according to the guidelines of the Declaration of Helsinki, and approved by the Institutional Ethics Committee of Zhongda Hospital Affiliated to Southeast University (protocol code 2019ZDKYSB083 and 8 February 2019).

Informed Consent Statement: Informed consent was obtained from all subjects and guardians involved in the study. Written informed consent has been obtained from the patient(s) and the guardians to publish this paper.

Data Availability Statement: The data presented in this study is available in supplementary material.

Acknowledgments: The authors are thankful to Juan Chen, a teacher of Tianhui Road Kindergarten, Jiangning District, Nanjing, China for her support.

Conflicts of Interest: All authors have read this paper and approved to submit it to this journal. There are no conflicts of interest for any authors in relation to the submission.

\section{References}

1. Barnes, M.A.; Carson, M.J.; Nair, M.G. Non-traditional cytokines: How catecholamines and adipokines influence macrophages in immunity, metabolism and the central nervous system. Cytokine 2015, 72, 210-219. [CrossRef]

2. Goldstein, D.S.; Kopin, I.J.; Sharabi, Y. Catecholamine autotoxicity. Implications for pharmacology and therapeutics of Parkinson disease and related disorders. Pharmacol. Ther. 2014, 144, 268-282. [CrossRef]

3. Eisenhofer, G.; Peitzsch, M. Laboratory Evaluation of Pheochromocytoma and Paraganglioma. Clin. Chem. 2014, 60, 1486-1499. [CrossRef] 
4. Schulze, J.; Vogelgesang, A.; Dressel, A. Catecholamines, steroids and immune alterations in ischemic stroke and other acute diseases. Aging Dis. 2014, 5, 327-339.

5. Bergquist, J.; Ściubisz, A.; Kaczor, A.; Silberring, J. Catecholamines and methods for their identification and quantitation in biological tissues and fluids. J. Neurosci. Methods 2002, 113, 1-13. [CrossRef]

6. Sangubotla, R.; Kim, J. Recent trends in analytical approaches for detecting neurotransmitters in Alzheimer's disease. Trends Anal. Chem. 2018, 105, 240-250. [CrossRef]

7. Chauhan, N.; Soni, S.; Agrawal, P.; Balhara, Y.P.S.; Jain, U. Recent advancement in nanosensors for neurotransmitters detection: Present and future perspective. Process. Biochem. 2020, 91, 241-259. [CrossRef]

8. Baranwal, A.; Chandra, P. Clinical implications and electrochemical biosensing of monoamine neurotransmitters in body fluids, in vitro, in vivo, and ex vivo models. Biosens. Bioelectron. 2018, 121, 137-152. [CrossRef] [PubMed]

9. Tokinoya, K.; Shishikura, Y.; Sekine, N.; Aoyagi, A.; Yoshida, Y.; Aita, Y.; Sugasawa, T.; Nabekura, Y.; Takekoshi, K. Plasma free metanephrine and normethanephrine levels correlated toplasma catecholamine after acute running in amateur runner. J. Exerc. Sci. Fit. 2021, 19, 178-181. [CrossRef]

10. Watson, A.M.D.; Gould, E.A.M.; Penfold, S.A.; Lambert, G.W.; Pratama, P.R.; Dai, A.; Gray, S.P.; Head, G.; Jandeleit-Dahm, K.A. Diabetes and Hypertension Differentially Affect Renal Catecholamines and Renal Reactive Oxygen Species. Front. Physiol. 2019, 10, 309. [CrossRef]

11. Lomae, A.; Nantaphol, S.; Kondo, T.; Chailapakul, O.; Siangproh, W.; Panchompoo, J. Simultaneous determination of beta-agonists by UHPLC coupled with electrochemical detectioin based on palladium nanoparticles modified BDD electrode. J. Electroanal. Chem. 2019, 840, 439-448. [CrossRef]

12. Huang, X.; Guo, X.-F.; Wang, H.; Zhang, H.-S. Analysis of catecholamines and related compounds in one whole metabolic pathway with high performance liquid chromatography based on derivatization. Arab. J. Chem. 2019, 12, 1159-1167. [CrossRef]

13. Chen, D.; Zhang, J.-X.; Cui, W.-Q.; Zhang, J.-W.; Wu, D.-Q.; Yu, X.-R.; Luo, Y.-B.; Jiang, X.-Y.; Zhu, F.-P.; Hussain, D.; et al. A simultaneous extraction/derivatization strategy coupled with liquid chromatography-tandem mass spectrometry for the determination of free catecholamines in biological fluids. J. Chromatogr. A 2021, 1654, 462474. [CrossRef]

14. Torul, H.; Gumustas, M.; Urguplu, B.; Uzunoglu, A.; Boyaci, I.H.; Celikkan, H.; Tamer, U. Disposable electrochemical flow cell with paper-based electrode assemble. J. Electroanal. Chem. 2021, 891, 115268. [CrossRef]

15. Zhou, X.; Zhu, A.; Shi, G. Selective extraction and analysis of catecholamines in rat blood microdialysate by polymeric ionic liquiddiphenylboric acid-packed capillary column and fast separation in high-performance liquid chromatography-electrochemical detection. J. Chromatogr. A 2015, 1409, 125-131. [CrossRef]

16. Tsuchiya, H.; Hayashi, T. High-performance liquid chromatographie analysis of catecholamines in biological samples by liquid/liquid extraction prepurification. J. Pharmacol. Methods 1990, 23, 21-30. [PubMed]

17. Betzabeth, E.B.M.; Fabienne, M.; Jérome, R.; Claire, D.; Vincent, D. Evaluation of boronate affinity solid-phase extraction coupled in-line to capillary isoelectric focusing for the analysis of catecholamines in urine. Anal. Chim. Acta 2018, 1034, $195-203$.

18. Woo, H.I.; Yang, J.S.; Oh, H.J.; Cho, Y.Y.; Kim, J.H.; Park, H.-D.; Lee, S.-Y. A simple and rapid analytical method based on solid-phase extraction and liquid chromatography-tandem mass spectrometry for the simultaneous determination of free catecholamines and metanephrines in urine and its application to routine clinical analysis. Clin. Biochem. 2016, 49, 573-579. [CrossRef]

19. Bicker, J.; Fortuna, A.; Alves, G.; Falcão, A. Liquid chromatographic methods for the quantification of catecholamines and their metabolites in several biological samples-A review. Anal. Chim. Acta 2013, 768, 12-34. [CrossRef] [PubMed]

20. Chen, L.; Wang, H.; Xu, Z.; Zhang, Q.; Liu, J.; Shen, J.; Zhang, W. High-throughput and selective solid-phase extraction of urinary catecholamines by crown ether-modified resin composite fiber. J. Chromatogr. A 2018, 1561, 48-55. [CrossRef]

21. Pan, S.; Zhang, Y.; Shen, H.; Hu, M. An intensive study on the magnetic effect of mercapto-functionalizednano-magnetic $\mathrm{Fe}_{3} \mathrm{O}_{4}$ polymers and their adsorption mechanism for the removal of $\mathrm{Hg}$ (II) from aqueous solution. Chem. Eng. J. 2012, 210, 564-574. [CrossRef]

22. Peng, L.; Qin, P.; Lei, M.; Zeng, Q.; Song, H.; Yang, J.; Shao, J.; Liao, B.; Gu, J. Modifying $\mathrm{Fe}_{3} \mathrm{O}_{4}$ nanoparticles with humic acid for removal of Rhodamine B in water. J. Hazard. Mater. 2012, 209-210, 193-198. [CrossRef] [PubMed]

23. Cui, W.; Xue, D.; Tan, N.; Zheng, B.; Jia, M.; Zhang, W. Pt supported on octahedral $\mathrm{Fe}_{3} \mathrm{O}_{4}$ microcrystals as a catalyst for removal of formaldehyde under ambient conditions. Chin. J. Catal. 2018, 39, 1534-1542. [CrossRef]

24. Guo, H.; Zhao, A.; He, Q.; Chen, P.; Wei, Y.; Chen, X.; Hu, H.; Wang, M.; Huang, H.; Wang, R. Multifunctional Fe $\mathrm{O}_{4} @ \mathrm{mTiO}_{2} @$ noble metal composite NPs as ultrasensitive SERS substrates for trace detection. Arab. J. Chem. 2019, 12, 2017-2027. [CrossRef]

25. Huang, Y.; Zhang, Y.; Liu, D.; Li, M.; Yu, Y.; Yang, W.; Li, H. Facile synthesis of highly ordered mesoporous $\mathrm{Fe}_{3} \mathrm{O}_{4}$ with ultrasensitive detection of dopamine. Talanta 2019, 201, 511-518. [CrossRef] [PubMed]

26. Haddaoui, M.; Sola, C.; Raouafi, N.; Korri-Youssoufi, H. E-DNA detection of rpoB gene resistance in Mycobacterium tuberculosis in real samples using $\mathrm{Fe}_{3} \mathrm{O}_{4}$ / polypyrrole nanocomposite. Biosens. Bioelectron. 2019, 128, 76-82. [CrossRef]

27. Han, Q.; Wang, X.; Yang, Z.; Zhu, W.; Zhou, X.; Jiang, H. $\mathrm{Fe}_{3} \mathrm{O}_{4} @ \mathrm{rGO}$ doped molecularly imprinted polymer membrane based on magnetic field directed self-assembly for the determination of amaranth. Talanta 2014, 123, 101-108. [CrossRef]

28. Babamiri, B.; Hallaj, R.; Salimi, A. Ultrasensitive electrochemiluminescence immunosensor for determination of hepatitis B virus surface antigen using CdTe@CdS-PAMAM dendrimer as luminescent labels and $\mathrm{Fe}_{3} \mathrm{O}_{4}$ nanoparticles as magnetic beads. Sens. Actuator B Chem. 2018, 254, 551-560. [CrossRef] 
29. Rajkumar, S.; Prabaharan, M. Multi-functional core-shell $\mathrm{Fe}_{3} \mathrm{O}_{4} @ \mathrm{Au}$ nanoparticles for cancer diagnosis and therapy. Colloids Surf. B Biointerfaces 2019, 174, 252-259.

30. Guan, H.; Liu, B.; Gong, D.; Peng, B.; Han, B.; Zhang, N. Direct electrochemical enhanced detection of dopamine based on peroxidase-like activity of $\mathrm{Fe}_{3} \mathrm{O}_{4} @ \mathrm{Au}$ composite nanoparticles. Microchem. J. 2021, 164, 105943. [CrossRef]

31. Bagheri, S.; Aghaei, H.; Ghaedi, M.; Asfaram, A.; Monajjemi, M.; Bazrafshan, A.A. Synthesis of nanocomposites of iron oxide/gold $\left(\mathrm{Fe}_{3} \mathrm{O}_{4} / \mathrm{Au}\right)$ loaded on activated carbon and their application in water treatment by using sonochemistry: Optimization study. Ultrason. Sonochem. 2018, 41, 279-287. [CrossRef] [PubMed]

32. Levi, N.; Khenkin, A.M.; Hailegnaw, B.; Neumann, R. Depolymerization of Cellulose in Water Catalyzed by Phenylboronic Acid Derivatives. ACS Sustain. Chem. Eng. 2016, 4, 5799-5803. [CrossRef]

33. Dutta, D.; Sailapu, S.K.; Chattopadhyay, A.; Ghosh, S.S. Phenylboronic Acid Templated Gold Nanoclusters for Mucin Detection Using a Smartphone-Based Device and Targeted Cancer Cell Theranostics. ACS Appl. Mater. Interfaces 2018, 10, 3210-3218. [CrossRef]

34. Vahlberg, C.; Linares, M.; Norman, P.; Uvdal, K. Phenylboronic Ester- and Phenylboronic Acid-Terminated Alkanethiols on Gold Surfaces. J. Phys. Chem. C 2011, 116, 796-806. [CrossRef]

35. Wang, M.; Ye, F.; Wang, H.; Admassu, H.; Feng, Y.; Hua, X.; Yang, R. Phenylboronic Acid Functionalized Adsorbents for Selective and Reversible Adsorption of Lactulose from Syrup Mixtures. J. Agric. Food Chem. 2018, 66, 9269-9281. [CrossRef] [PubMed]

36. Baker, G.; Desikan, R.; Thundat, T. Label-Free Sugar Detection Using Phenylboronic Acid-Functionalized Piezoresistive Microcantilevers. Anal. Chem. 2008, 80, 4860-4865. [CrossRef] [PubMed]

37. Sankoh, S.; Thammakhet, C.; Numnuam, A.; Limbut, W.; Kanatharana, P.; Thavarungkul, P. 4-mercaptophenylboronic acid functionalized gold nanoparticles for colorimetric sialic acid detection. Biosens. Bioelectron. 2016, 85, 743-750. [CrossRef]

38. Liu, L.; Cheng, C.; Chang, Y.; Ma, H.; Hao, Y. Two sensitive electrochemical strategies for the detection of protein kinase activity based on the 4-mercaptophenylboronic acid-induced in situ assembly of silver nanoparticles. Sens. Actuators B Chem. 2017, 248, 178-186. [CrossRef]

39. Mo, G.; He, X.; Zhou, C.; Ya, D.; Feng, J.; Yu, C.; Deng, B. A novel ECL sensor based on a boronate affinity molecular imprinting technique and functionalized SiO2@CQDs/AuNPs/MPBA nanocomposites for sensitive determination of alpha-fetoprotein. Biosens. Bioelectron. 2019, 126, 558-564. [CrossRef] [PubMed]

40. Chen, L.-Q.; Wang, Y.; Qu, J.-S.; Deng, J.-J.; Kang, X.-J. Selective extraction of catecholamines by packed fiber solid-phase using composite nanofibers composing of polymeric crown ether with polystyrene. Biomed. Chromatogr. 2015, 29, 103-109. [CrossRef]

41. Özdemir, N.; Çakır, A.; Somtürk, B. Boronic acid functionalized polymeric microspheres for catecholamine isolation. Colloids Surf. A Physicochem. Eng. Asp. 2014, 445, 40-47. [CrossRef]

42. Xie, L.; Chen, L.; Gu, P.; Wei, L.; Kang, X. A Convenient Method for Extraction and Analysis with High-Pressure Liquid Chromatography of Catecholamine Neurotransmitters and Their Metabolites. J. Vis. Exp. 2018, 133, e56445. [CrossRef] [PubMed] 